\title{
Waste recycling: share in the structure of the tariff for the treatment of solid municipal waste in the Vologda region
}

\author{
Ekaterina Solov'eva ${ }^{1, *}$, Marina Popova ${ }^{2}$, and Denis Pogodin ${ }^{3}$ \\ ${ }^{1}$ Vologda State University, 160000, Lenina st.,15 Vologda, Russia \\ ${ }^{2}$ International association of fire, industrial and environmental safety specialists, 125047, Third Tverskaya - Yamskaya st., 10, Moscow, \\ Russia \\ ${ }^{3}$ Moscow State University of Civil Engineering, 129337, Yaroslavskoe shosse, 26, Moscow, Russia
}

\begin{abstract}
In the modern world, the issues of solid municipal waste disposal, as part of the problem of environmental protection, are quite acute These problems are relevant for Russia and for many other world powers. The Russian Federation is one of the most polluted countries in the world, which negatively affects the quality of life and the health of the population of its regions. The annual increase in the volume of municipal solid waste is part of the man-made impact of man on the natural environment. To make strategic decisions on this issue, it is necessary to understand the policy of MSW management, so the authors in the article consider the values of tariffs for MSW management in one of the major regions of Russia - the Vologda Region. The data of tariffs of the Vologda region approved for 2021 are given. The structure of the average tariffs of the Russian Federation and the Vologda Region is analyzed. On the basis of regional regulations, a sample of data on the costs of disposal and transportation of MSW for some districts of the Vologda region is given: Velikoustugski, Totemski, Mezhdurechensky, Babushkinsky area, Belozersky districts. The average values of tariffs for the treatment of MSW for Russia and other countries are given: the USA, Canada, Germany, France and Finland. In addition to tariffs, the authors conducted a study on the distribution of MSW by type of disposal: disposal, incineration and recycling The article discusses the values of tariffs for the treatment of solid municipal waste and their disposal. In conclusion, the authors express concern about insufficient funds for innovations in the field of MSW processing/ recycling.
\end{abstract}

\section{Regulatory documents on tariffs}

In the modern world, the issues of solid municipal waste disposal, as part of the problem of environmental protection, are quite acute These problems are relevant for Russia and for many other world powers. The Russian Federation is one of the most polluted countries in the world, which negatively affects the quality of life and the health of the population of its regions. The annual increase in the volume of municipal solid waste is part of the man-made impact of man on the natural environment.

The integrated system of waste management, which includes effective methods of processing production and consumption waste, in our country is based on the federal projects "Clean Country", "Integrated system of solid municipal waste management" included in the national project "Ecology" [1].

As part of the implementation of the regional project "Integrated System of Solid Municipal Waste Management" in 2020, an inter-budget transfer was allocated from the federal budget to the budget of the Vologda Region in the amount of 78,351.3 thousand rubles for the implementation in 2020 of measures to ensure the provision of public services to the population for the management of solid municipal waste. MSW management is the collection of MSW at special sites, sorting, removal, disposal or recycling, i.e. recycling of MSW. It is known that a small part of waste is recycled in Russia, no more than $8 \%$ (according to some media reports, $4.4 \%$ ) [2].

According to Article 24.6 of the Federal Law of 24.06.1998 N 89-FZ "On production and consumption waste "'collection, transportation, processing, disposal, neutralization, burial of solid municipal waste in the territory of the subject of the Russian Federation is provided by one or more regional operators in accordance with the regional program in the field of waste management and the territorial scheme of waste management". This means that the funds for recycling are included in the tariff for waste management.

According to the Decree of the Government of the Russian Federation of 30.05.2016 N 484 "On pricing in the field of solid municipal waste management" in the Vologda region, two types of tariffs are defined for the population (item II. 6):

- the rate at which the disposal of solid municipal waste, including the properties of solid municipal waste is included in accordance with suncom 8 of article 29.1 of the Federal law "On wastes of production and

\footnotetext{
* Corresponding author: evsvologda $@$ mail.ru
} 
consumption" in the list of properties of solid municipal waste in the territory of the Russian Federation $[5,6]$.

When setting tariffs, the tariff regulatory body (in the Vologda Region, the Department of Fuel and Energy Complex and Tariff Regulation-DTEKiTR) must use economically reasonable volumes of consumption of raw materials, materials, works (services) performed and prices (tariffs) for them, taking into account various types of expenses (VI Government resolutions of 30.05.2016 N 484):

* production:

a) expenses for the purchase of raw materials and their storage;

b) the cost of purchased fuel, electric energy (capacity), thermal energy (capacity), and other types of energy resources (hereinafter referred to as energy resources);

c) expenses for payment of works and (or) services performed by third-party organizations or individual entrepreneurs related to the operation of facilities used for processing, neutralization, and disposal of MSW;

d) labor costs and social contributions for the main production personnel;

e) expenses for the payment of interest on

g) other operating expenses

* repair costs.

* administrative expenses;

- sales expenses;

* depreciation expense on fixed assets and intangible assets;

* expenses for rent, lease payments, concession fees, taking into account the specifics provided for in this document;

* expenses related to the payment of taxes, fees and other mandatory payments;

* expenses for the payment of goods, works and services of other operators for the management of solid municipal waste;

* regulatory profit margin

* the cost of payment for the negative impact on the environment when placing solid municipal waste, etc. according to the document.

\section{Analysis of rates}

Figure 1 shows the average cost distribution in the MSW management tariff: the main items are shown here: transportation costs, disposal costs, collection and sorting costs, operator costs, and so on. Figure 2 shows the structure of the tariff of the regional operator of the Vologda region "Aqualine". The presented percentages of the total value of tariffs for the treatment of MSW have values that differ within $10 \%$, for example, collection and transportation-56.5 and 47\%; disposal-21 or $28 \%$.

For information: The Vologda Region is formed, according to the approved Territorial Waste Management Scheme (DTEKiTR Order No. 174 of 29.12.2016), including with MSW of approximately 495,000 tons of MSW per year. With an average density of $140 \mathrm{~kg} /$ cubic meter, this is 3.5 million cubic meters per year.

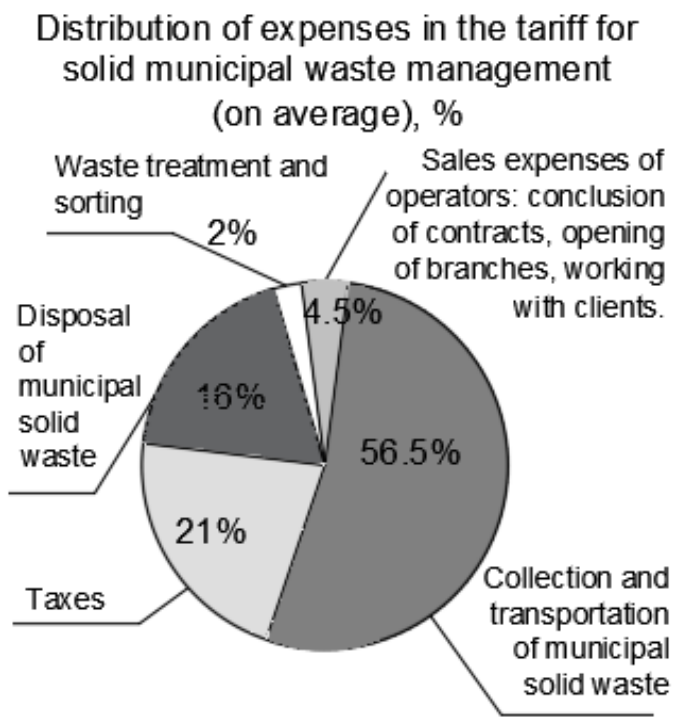

$0 \%$ - The tariff does not include: purchase, maintenance, repair of garbage containers. It is carried out at the expense of regional operators. $0 \%$ - The profit of regional operators is not included in the tariff.

Fig. 1. Average values of the cost distribution in the tariff for the treatment of MSW [3].

\section{The structure of the regional operator's tariff for 2019.}

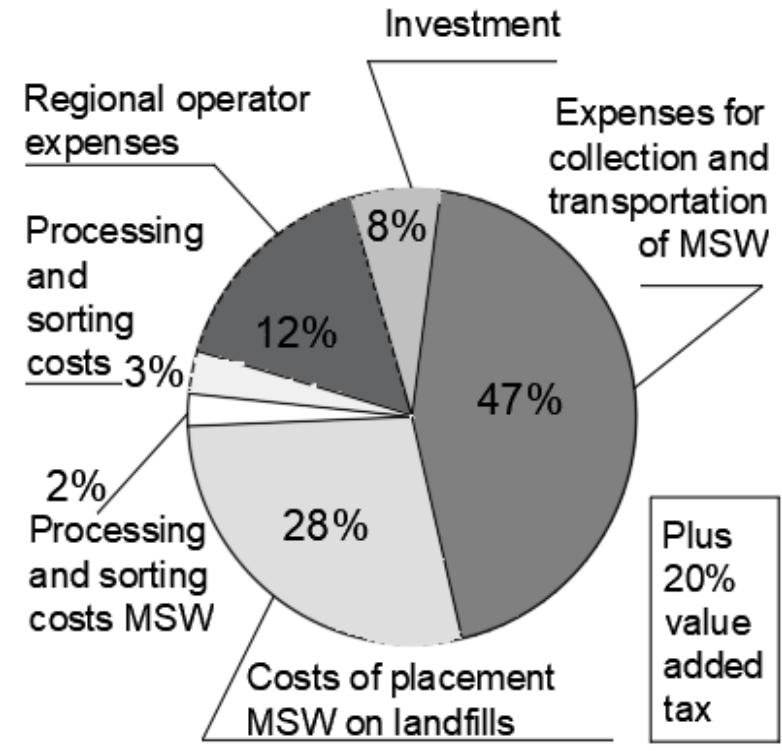

Fig. 2. The structure of the tariff of the regional operator of the Vologda region "Aqualine"[4].

In December 2020, the orders of the Department of Fuel and Energy Complex and Tariff Regulation of the Vologda Region established the maximum tariffs for the service of two regional operators "Aqualine" and "Clean Trace" for the treatment of solid municipal waste (Order No. 603-r of 17.12.2020 and Order No. 605-r of 17.12.2020 ) (Fig. 2). 
Table 1. Costs for the disposal of MSW in the structure of the tariff of the operator "Aqualine" for 2021-2023.

\begin{tabular}{|c|c|l|l|c|}
\hline Years & 2021 period & $\begin{array}{l}\text { Single rate of } \\
\text { treatment } \\
\text { with MSW, } \\
\text { RUB/cubic } \\
\text { meter. }\end{array}$ & $\begin{array}{l}\text { Average tariff } \\
\text { for the disposal } \\
\text { of MSW, } \\
\text { RUB/cubic } \\
\text { meter. }\end{array}$ & $\begin{array}{l}\text { Percentage } \\
\text { in the tariff } \\
\text { structure }\end{array}$ \\
\hline \multirow{2}{*}{2021} & $1.01-30.06$ & 527.32 & 269.6 & 51 \\
\cline { 2 - 5 } & $1.07-31.12$ & 545.14 & 298.5 & 55 \\
\hline \multirow{2}{*}{2022} & $1.01-30.06$ & 545.14 & 287.2 & 53 \\
\cline { 2 - 5 } & $1.07-31.12$ & 565.06 & 287.2 & 51 \\
\hline \multirow{2}{*}{2023} & $1.01-30.06$ & 565.06 & 287.6 & 51 \\
\cline { 2 - 5 } & $1.07-31.12$ & 577.18 & 293.6 & 51 \\
\hline
\end{tabular}

The calculation showed that in the Vologda Region, $52 \%$ of the cost of handling MSW is laid down for disposal, which is more than twice the established norm about $25 \%$.

\section{Transportation costs}

The Department of Natural Resources and Environment of the Vologda Region has submitted a draft Order "On amendments to the territorial scheme of waste management, including solid municipal waste, on the territory of the Vologda region", where in Table 1 (see Table 2), the values of distances from the settlements of the Vologda region to the landfill, the place of disposal of MSW are presented. As you can see, the movement of MSW can be at a distance of up to $220 \mathrm{~km}$. Thus, the component in the structure of the tariff for transport costs is unlikely to decrease from the $47 \%$ set by the operator "Aqualine" (Fig.2.).
Table 2. Placement of MSW in the Vologda region, with a distance of more than $100 \mathrm{~km}$ to the landfill.

\begin{tabular}{|c|c|c|c|}
\hline $\begin{array}{l}\text { District of } \\
\text { Vologda } \\
\text { region }\end{array}$ & $\begin{array}{l}\text { Placement object } \\
\text { (polygon) }\end{array}$ & $\begin{array}{l}\text { Mass of } \\
\text { waste } \\
\text { that has } \\
\text { been } \\
\text { disposed } \\
\text { of } \\
\text { (thousan } \\
\text { d tons) }\end{array}$ & $\begin{array}{l}\text { The } \\
\text { average } \\
\text { of the } \\
\text { distance } \\
\text { to the } \\
\text { landfill } \\
(\mathrm{km})\end{array}$ \\
\hline $\begin{array}{l}\text { Babushkin- } \\
\text { sky district }\end{array}$ & $\begin{array}{l}\text { Solid waste landfill, } \\
\text { city Sokol (limited } \\
\text { liability company } \\
\text { «Komus») }\end{array}$ & 4.810 & 220.0 \\
\hline \multirow{2}{*}{$\begin{array}{l}\text { Velikoustug } \\
\text {-sky district }\end{array}$} & $\begin{array}{l}\text { Landfill for the } \\
\text { disposal of industrial, } \\
\text { solid household waste, } \\
\text { cityTarnoga (limited } \\
\text { liability company } \\
\text { «Tarnoga - } \\
\text { Zhilkomservis ») }\end{array}$ & 12.495 & 190.0 \\
\hline & $\begin{array}{l}\text { Landfill for the } \\
\text { disposal of industrial, } \\
\text { solid household waste } \\
\text { limited liability } \\
\text { company } \\
\text { «Agroremtehsnab» }\end{array}$ & 12.495 & 140.0 \\
\hline $\begin{array}{l}\text { Mezhdure- } \\
\text { chensky } \\
\text { district }\end{array}$ & $\begin{array}{l}\text { Landfill for the } \\
\text { disposal of industrial, } \\
\text { solid household waste, } \\
\text { city Sokol (limited } \\
\text { liability company } \\
\text { "Komus") }\end{array}$ & 0,19 & 130,0 \\
\hline $\begin{array}{l}\text { Totemsky } \\
\text { district }\end{array}$ & $\begin{array}{l}\text { Landfill for the } \\
\text { disposal of industrial, } \\
\text { solid household waste, } \\
\text { city Sokol (limited } \\
\text { liability company } \\
\text { "Komus") }\end{array}$ & 8.239 & 190.0 \\
\hline $\begin{array}{l}\text { Belozer- } \\
\text { skiy } \\
\text { district }\end{array}$ & $\begin{array}{l}\text { Landfill for the } \\
\text { disposal of industrial, } \\
\text { solid household waste } \\
\text { (limited liability } \\
\text { company "Polygon") }\end{array}$ & 6.052 & 120.0 \\
\hline
\end{tabular}

Table 3 contains data on the amount, types of MSW disposal and average tariffs per person for MSW handling in dollars per year. It also includes the percentage of spending on the average of the wages of residents of Russia and other countries: the USA, Germany, Canada, France and Finland on the treatment of MSW. The analysis of the given information makes it possible to draw a conclusion: with almost equal deductions of residents for municipal services-waste management, in Russia, the most non - modern, bringing great harm to nature, type of disposal-burial still prevails. In the countries of Canada and Finland, the MSW tariff is included in the total cost of housing maintenance, or residents pay for a specific accumulated waste [7]. 
Table 3. Comparison of the MSW management system in different countries.

\begin{tabular}{|l|c|c|c|c|c|c|}
\hline & Russia & USA & Canada & Germany & France & Finland \\
\hline $\begin{array}{l}\text { The amount } \\
\text { of MSW } \\
\text { generated, } \\
\text { MT. }\end{array}$ & 56 & 262 & 34 & 53 & 28 & 2,9 \\
\hline Bury,\% & 94 & 52 & 75 & 1 & 22 & 3 \\
\hline Burning,\% & 2 & 13 & 8 & 33 & 36 & 53 \\
\hline Recycling,\% & 4 & 35 & 17 & 66 & 42 & 44 \\
\hline $\begin{array}{l}\text { The amount } \\
\text { of MSW } \\
\text { generated } \\
\text { per person, } \\
\text { tons/year }\end{array}$ & 0.48 & 0.82 & 0.4 & 0.4 & 0.53 & 0.5 \\
\hline $\begin{array}{l}\text { Average rate } \\
\text { of one } \\
\text { person per } \\
\text { service - } \\
\text { handling of } \\
\text { MSW, USD } \\
\text { / year }\end{array}$ & $16-24$ & $\begin{array}{l}150- \\
260\end{array}$ & - & $165-330$ & $125-$ & - \\
\hline $\begin{array}{l}\text { Percentage } \\
\text { of salary,\% }\end{array}$ & $0,5-0,8$ & $\begin{array}{l}0,3- \\
0,5\end{array}$ & - & $0,3-0,5$ & $0,3-0,5$ & - \\
\hline
\end{tabular}

Thus, analyzing the above information, we can formulate a conclusion: for innovative projects for the collection, sorting and recycling of MSW in the Vologda Region, in particular, and in Russia in general, the minimum amount of funds is allocated, because basically, the entire amount of utility fees from the population is directed to the disposal and transportation of MSW.

Financing of MSW recycling facilities in developed civilized world powers is based on the balance of business and state interests, therefore, only the improvement of the integrated system for preventing the formation of MSW, development of infrastructure for the disposal of MSW, solving the problem of financial management of MSW, as well as the implementation of state programs to address them, It will allow us to solve one of the most acute environmental problems in Russia in the shortest possible time .

Thus, analyzing the above information, we can formulate a conclusion: the minimum amount of funds is allocated for innovative projects for the collection, sorting and recycling of MSW in the Vologda region, since basically the entire amount of municipal fees from the population is directed to the disposal and transportation of MSW. The authors of the article devoted a number of their scientific developments and scientific publications to the issues of recycling [8-15].

\section{Conclusion}

Thus, analyzing the above information, we can formulate a conclusion: the minimum amount of funds is allocated for innovative projects for the collection, sorting and recycling of MSW in the Vologda region, since basically the entire amount of municipal fees from the population is directed to the disposal and transportation of MSW.
The authors of the article devoted a number of their scientific developments and scientific publications to the issues of recycling [7-15].

\section{References}

1. V. Timofeev, A. Ponomarenko, L. Tolmacheva, Analysis of solutions to the problem of waste disposal in various countries, IN the book: Science and Modernity, Materials of the Regional Scientific and Practical Conference (2018)

2. The problem of implementing a system of selective collection of household waste in Russia, Safety of the urban environment, Proceedings of the VI International Scientific and Practical Conference, Under the general editorship of E. Yu. Tyumentseva (2019)

3. O. Ustinova, E. Kuminova, Solving the "garbage problem" in russia, Land, water, climate of Siberia and the Arctic in the XXI century: problems and solutions, collection of reports of the International Scientific and Practical Conference (2014)

4. A. Ivanov, M. Balanovsky, S. Kondratenko, organizational, economic and legal problems of effective implementation of the mechanism of extended producer responsibility in the field of waste management, Actual Problems of Economics and Law, 2 (2020)

5. V. Maksimov, Tariffs in the sphere of solid municipal waste management: problems and prospects, Young scientist, 16 (2016)

6. S. Pupynina, Tariff regulation in the field of solid municipal waste management, Young scientist, 13 (2016)

7. M. Popova, A. Zhukov, Polymers and effective polymer materials, Scientific Review, 10 (2015)

8. E. Solov'eva, Experimental studies of polyvinyl chloride stress relaxation, Science, technology, education, 8 (2015)

9. E. Solov'eva, T. Matseevich, A. Askadsky, M. Popova, O. Kovriga, Influence of plasticization on the elastic modulus of glass-like polymers, Internet-vestnik VolgGASU, 2 (2014)

10. E. Solovyova, O. Pakhneva, Physical and mechanical studies of secondary polypropylene, In the collection: Effective building structures: theory and practice, Collection of articles of the XVIII International Scientific and Technical Conference (2018)

11. X. Zhang, T. Matseevich, A. Askadskii, M. Popova, O. Serenko, The calculation scheme for prediction both of storage and loss moduliLiu, AIP Conference Proceedings, 1. "Materials Science, Energy Technology, and Power Engineering I: 1st International Conference on Materials Science, Energy Technology, Power Engineering" (2017) 
12. M. Popova, F. Xu, S. Jiang, E. Kurskaya, A. Askadskii, T. Matseevich, The calculation scheme for prediction of viscosity for polymeric nano-suspensions, AIP Conference Proceedings, 1. "Materials Science, Energy Technology, and Power Engineering I: 1st International Conference on Materials Science, Energy Technology, Power Engineering" (2017)

13. M. Popova, R. Dokuchaev, A. Golovanov, The use of polymer technogenic waste as raw materials for non-metallic reinforcement, Promising polymer composite materials, alternative technologies, Recycling, application, ecology ("Composite-2016") (2016)

14. T. Matseevich, A. Askadsky, M. Popova, O. Kovriga, The rubbery modulus of nanocomposites based on styrene butadiene rubber, International Polymer Science and Technology, 9 (2016)

15. T. Matseevich, A. Askadsky, M. Popova, E. Afanas'ev, Calculation scheme for evaluation and prediction of water permeability through polymer membranes, Reports Physical Chemistry, 2 (2015).

16. M.I. Ermilova, S.V. Laptev, Using the system-functional approach to assess the development of housing construction, E3S Web of Conferences, 220, 01001 (2020) 